\title{
Theoretical presumptions of learning a foreign language through global citizenship development at pre-primary school
}

\author{
Vaida Žegunienè \\ Klaipèda University, Lithuania; vaidazeg@gmail.com
}

\begin{abstract}
The paper aims to demonstrate a new efficient and relevant trend closely related to the language learning where the main emphasis is on the development of global citizenship. Furthermore, revealing the theoretical presumptions of learning a foreign language, it will be purposefully targeted at crystallization of a notion global citizenship. After having reviewed the documents regulating education policy, it was identified that global citizenship is described as democratic and sustainable education that specifically is focused on the development of a global citizen who is able to understand the social issues, activities and processes of the contemporary society, to demonstrate a tolerant and positive approach and to adapt to the global environment. It is emphasized that global citizenship is a core of the growth of a global citizen and his/her proactive performance in the global context, which indisputably comprises various countries, cultures, values, beliefs, etc. The analysis of the documents, studies and reports revealed the theoretical presumptions that learning a foreign language is tightly related to global citizenship education that is recommended to be initiated at pre-primary school because the pre-primary school aged children are capable to form/construct new global skills (including language/communication skills). Thus, the initiation of global citizenship education and its combination with learning a foreign language might be considered as a must due to the beneficial aspects for education of the pre-primary school aged learners.
\end{abstract}

Keywords: language learning, foreign language, global citizenship education, global citizen, pre-primary education, pre-primary school aged children

\section{Introduction}

Currently, it is obviously seen that the process of globalization makes an impact on the personal and professional life of people. Due to constant changes in the global society, the citizens have to be aware of global innovations, to understand the existing and newly arising social concerns and to guarantee wealthy personal existence. Technological and scientific advancement, global relationships with various countries, cultures and people changed and expanded the notion of national identity, and that expansion could be acknowledged as an obstacle for the sufficient performance in the global community (Tarozzi 2016, Sy 2017). A process of integration of innovations into personal life is apparent when observing life of the youth who may be called the Internet addicts. They prefer a virtual lifestyle, an active surfing the Internet, a virtual interaction with peers on the social networks, and they are engaged into great variety of virtual activities (Thorne \& Black 2007, Blattner \& Fiori 2011, Twigg, Pendergast \& Twigg 2015).

Many educators, scholars and practitioners (Osler \& Starkey 2005, Thorne \& Black 2007, Ortega 2009, Blattner \& Fiori 2011, Žegunienè, Parisauskiene \& Jankauskiene 2012, Tuomaitè 2014) discuss how to develop learners' foreign language skills and competences needed for their further personal and professional life. It is not enough to master languages; it is important to combine traditional skills with the modern ones. Therefore, the global community and its members have to acquire the skills of a foreign language, to deepen intercultural awareness and to develop a capability to be flexible, shifting among various forms and conditions of the communication process. (Richards \& Renandya 2002). That leads to a new conception of the process of learning a foreign language that nowadays is more closely related to global citizenship education.

The paper targets on a familiarization with the theoretical presumptions of learning a foreign language through global citizenship development and the definition of the notion of global citizenship. Global citizenship is mentioned in various documents, study reports related to the regulatory principles of educational policy (the Council of Europe 2008, The Parliament of Europe 2012, Tarozzi 2016, UNESCO 
2013, 2014a, 2014b, 2017, OECD 2018). The meaning of this phenomenon is clarified as a strand of global education focused on education of a global citizen who is capable: '...to become aware of activities taking place in the contemporary global environment; to act in a positive manner under the crosscultural circumstances; to be flexible and adaptable to the fast-changing global perspectives.' (Global citizenship education: Preparing learners for the challenges of the 21st century 2014b: 17).

In today's world influenced by diverse innovations and multinational companies, the relationship among countries, cultures and languages (as an integral part of every culture) and their impact on the peoples' life cannot be denied (Block \& Cameron 2002). As a global citizen, every learner has to be familiar with a convergence of cultures and languages (a mother tongue and a foreign language). So, this approach allows learners to understand that a (foreign) language is a tool for communication, and following this strand, it is a tool for understanding cultures, countries and people (Vereshagin \& Kastamarov 1990, Porto 2013).

Considering the global changes in the society, the educational needs and demands of a young generation need to be satisfied taking into consideration global education. Those learners who obviously demonstrate addiction to technology and virtual activities insist on new teachers' competences to be developed. That leads to the fact that the teachers have to be seriously focused on the development of new competences and possibilities to integrate innovations into the process of teaching and to acknowledge that education of the young learners is a constitutive part of the international context (Augustiniene \& Pociene 2016, Ortega 2009, Osler \& Starkey 2005).

The underlying theoretical presumptions, presented in the paper, declare that development of the foreign language skills as well as knowledge about the local, national and international contexts have to be initiated at early childhood. The Lithuanian and international scholars (Jorgenson 2010, Augustiniene \& Pociene 2016, Tarozzi 2016, Hainsworth 2017, Sy 2017) accentuate that the pre-primary school aged learners have the specific abilities and demonstrate willingness to broaden one's horizons, to construct practical and theoretical understanding of a surrounding environment and to construe information to form the skills of a new foreign language through the relations with peers and other people.

The paper aims to crystallize theoretically how learning a foreign language might be initiated integrating global citizenship into the curriculum of pre-primary school education. The object: learning a foreign language through global citizenship development educating the pre-school aged children. Tasks: 1) to clarify the concept 'a global citizen'; 2) to investigate the theoretical opportunities for initiation of global citizenship at pre-primary school; 3) to reveal the theoretical presumptions of learning a foreign language through global citizenship development.

Methods. The content analysis, synthesis and generalization of the documents discussing the current and future educational decisions and actions to be taken in Europe and Lithuania (IBE-UNESCO 2018, OECD 2018, the United Nations 2012, 2018, UNESCO, 2013, 2014a, 2014b, 2015, 2017, OXFAM 2015, Conception of Global Education 2015, European Parliament 2012, The Council of Europe 2008, the Ministry of Science and Education of the Republic of Lithuania 2018, etc.) where the concept of global citizenship education is revealed in various perspectives as well as its significance for a global citizen. The multilingualism policy is reviewed in the mentioned documents, and in addition, the aspect how to learn a foreign language through the development of global citizenship at pre-primary school.

\section{Theoretical analysis of the concept global citizenship}

In the Maastricht Global Education Declaration (2002), global education is explained as a very complex notion comprising the fields as: development education, human rights education, education for sustainability, education for peace and conflict prevention and intercultural education. Furthermore, global education comprises the global element of education for citizenship. The Declaration explains that global education is 'education that opens people's eyes and awakens them to bring greater justice, equality and human rights for all.' (Maastricht Global Education Declaration 2002: 13) 
The greater part of sources stated that the newly occurred circumstances of the contemporary society demonstrate an essential requirement to promote a multicultural dialogue, respect and understanding (Carvalho de Silva 2019, Jorgenson 2010, Mundy 2007). The former approaches are not sufficient any more due to the growing cross-cultural awareness and the expansion of a worldview (identity). Identity building and its supplementation with the global elements are emphasized by the White Paper (the Council of Europe, 2008). 'Person's national identification combines the features and components of the national historical heritage, family background, cultural heritage, social background, 'freedom to choose and act responsibly' and 'a central aspect of human rights.' (The White Paper 2008: 18).

In the era of constant globalization and internationalization, modernized humanity has been raising questions and expressing concerns regarding global education. That leads to the belief that empowering learners to become the active global citizens is a key issue of many international institutions and organizations that take the measures concerning implementation of global citizenship education throughout the whole world (UNESCO 2013, 2014a, 2014b, 2015, 2017). Global citizenship education supplies young children, teenagers and other learners with necessary knowledge, values, attitudes and skills to understand, create and sustain people's lives locally, nationally and globally. (UNESCO 2013, 2014a, 2014b, 2015, 2017)

In the twenty-first century the education institutions and organizations must cope with new questions related to internationalization of curriculum, to meet new demands of the young learners and to revisit their thinking and action frameworks (The United Nations Secretary-General 2012, Oxfam 2015, OECD 2018). As the documents of the European Union and the United Nations organizations emphasize global citizenship education is a new world model; it functions as a constituent system that influences how citizenship operates. A global frame does not replace attention to the national and local issues. Rather this frame re-orients citizenship education so that learners become aware of the issues and the factors at many levels that shape the world around them (UNESCO 2013, 2014a, 2014b, IBE-UNESCO 2018, OECD 2018, CONCORD 2018).

Attempting to provide the readers with a more precise explanation of global citizenship, OXFAM (2015) has formulated an explanation of a global citizen taking into account the elements such as knowledge, skills, values and attitudes needed and to be developed while educating the young learners within the global context. A global citizen:

- is familiar with the global setting and knows the exact personal place and role;

- feels deep admiration for the existing diversity;

- knows how the world is structured and how the particular fields (culture, technologies, environment) are organized and managed;

- demonstrates a strong reaction to the social issues (injustice, poverty, inequality, etc.);

- demonstrates deep inner motivation to create and retain the world as a better and safer place;

- participates in civic activity, demonstrates positive behavior, promotes own contribution creating better local, regional, national and global community. (OXFAM 2015: 5).

Analysis of the documents revealed a fact that the pre-primary schools, the schools of basic education, the youth clubs, etc. are the main places to learn interculturally. (Council of Europe 2008: 33). Sulivan (2018), vice president of the European umbrella organization CONCORD, presented the international study "Global Citizenship Education in Europe: How much do We Care?" where it was noted that it is significantly important to integrate the topics of global education into the curriculum of pre-primary and basic education and to apply innovative teaching/learning methods such as '... workshops/seminars, specialized training, summer schools, discussions, art workshops, theatre, films, excursions, voluntary activities in the closest community' (Global Citizenship Education in Europe: How much do We Care? 2018: 17).

The review of the documents revealed that global citizenship education is closely interconnected with the modern society and appearing technological and educational innovations. The field of global 
education effects awareness of the modern society and existing issues, and it plays a vital role in knowledge construction and other educational processes at pre-primary school. The pre-primary school desires to assist children while acquiring/constructing knowledge, skills and behavior patterns which will form a basis for further education at basic and secondary school. Pre-schoolers have to be able to demonstrate appropriate behavior patterns and motivation to act like the citizens of own country, but this citizenship has to be extended with the global aspects.

\section{Learning a foreign language and global citizenship at pre-primary school}

Language(s) are invented and used to satisfy the basic needs of human beings: to communicate, to socialize, to acquire and exchange knowledge, to reflect the gained experience, to form new skills and patterns of behavior (Bakhtin 1986, Driscoll 2000). Consequently, this directs to understanding that a true meaning and value of language is educational with a purpose to educate a global citizen. Using the concept of a global citizen it is understood that a person is open to a multicultural dialogue and has a right to get familiar with the surrounding world. More languages a person speaks more opportunities (s)he has to demonstrate globality of own personality. Learning a foreign language is a treasure and it may influence the growth of children identity. (Vereshagin \& Kastamarov 1990).

Considering a multicultural dialogue and the international perspectives the young learners have to be encouraged to investigate own identity and culture, to expand own worldview and interpretation of the common notions, to think critically and creatively about one's role in the world, to establish rapport with the peers and people from different cultures and to be tolerant. Thus, observing the educational context through the international prism, global citizenship propagates learning and usage of a foreign language (for instance, the most popular internationally - English). Every foreign language helps a young learner to develop the senses of empathy, tolerance, respect and a capability to recognize/identify own characteristics, and particularly, a position in the local, national and global communities. Moreover, the usage of a foreign language enlarges learners' mentality and horizons, and it develops thinking and creativity skills. Global citizenship makes wider contexts available for the young learners and provide them with more educational chances to analyze cultural factors (for instance, literature, history, art, etc.). That leads to the formation/construction of the personal 'global' values, assumptions and a sense of global identity (Zalavinab \& Kisel 2016). It is recommended to begin the process of familiarization with the closest environment and native country and move to the global surroundings. The young learners have to be familiarized with fairy tales, legends or myths which can help them to identify themselves and to determine own place in the community. Then moving towards the global context, the learners will be acculturated easier (Osler \& Starkey 2005, Gimenez \& Sheehan 2008, Twigg, Pendergast \& Twigg 2015).

Nowadays working with the young learners, teachers have to consider possibility to relate the process of teaching/learning a foreign language to the global citizenship development. As Osler \& Starkey (2005) note the benefit for the young learners is as follows:

- development of the skills effecting ability to communicate, to think critically and creatively;

- motivation to deepen cultural awareness and to construct own values and beliefs;

- development of foreign language literacy that may indicate a level of cosmopolitism and its impact on learning other languages;

- enabling the learners to practice a foreign language in a native country and outside its borders;

- to be engaged in 'real-life' learning (learning-on-the-spot) where four skills of a foreign language usage (reading, speaking, listening and writing) are employed and combined. Thus, learning is more attractive and meets demands of the young generation to interconnect reality and the theoretical aspects;

- motivation to deepen learners' understanding of the local and global issues through the process of learning a foreign language; 
- challenging the learners' current perspectives and values, stimulating the learners to reflect and share own perspectives and to construct new knowledge and worldview;

- encouragement to see and value diversity of the world and to demonstrate a positive approach to the opinion of others;

- giving the learners confidence to share/reflect their acquired knowledge, formed values, developed skills, and enhanced motivation. (Osler \& Starkey 2005).

A foreign language is a primary medium of the social interaction (Vereshagin \& Kastamarov 1990, Block \& Cameron 2002, Osler \& Starkey 2005). That interaction is constructed and maintained through the social relations during the everyday situations. The young learners have to elaborate on the expansion of foreign language skills, to form and develop new skills and competences that are important for being a global citizen. According to Bakhtin (1986), a link between language and life is undisputable. From Bakhtin's point of view, language constitutes and is constitutive of life itself, studying utterances in particular contexts it is possible to understand their meanings (Bakhtin 1986: 63). As Figure 1 illustrates, people are connected with the global environment which creates the proper conditions for global knowledge acquisition and development of new skills and competences. This process cannot be implemented without a language and a foreign language due to globalization, merging of cultures and different lifestyles. Moreover, the learners have to perceive new global conditions appropriately because misunderstandings might lead to the social issues. Global citizenship education aims to reduce a scope of the existing social issues, but that is impossible without proper communication, and that results in necessity to know foreign language.

Figure 1: Connection between a foreign language and global citizenship education.

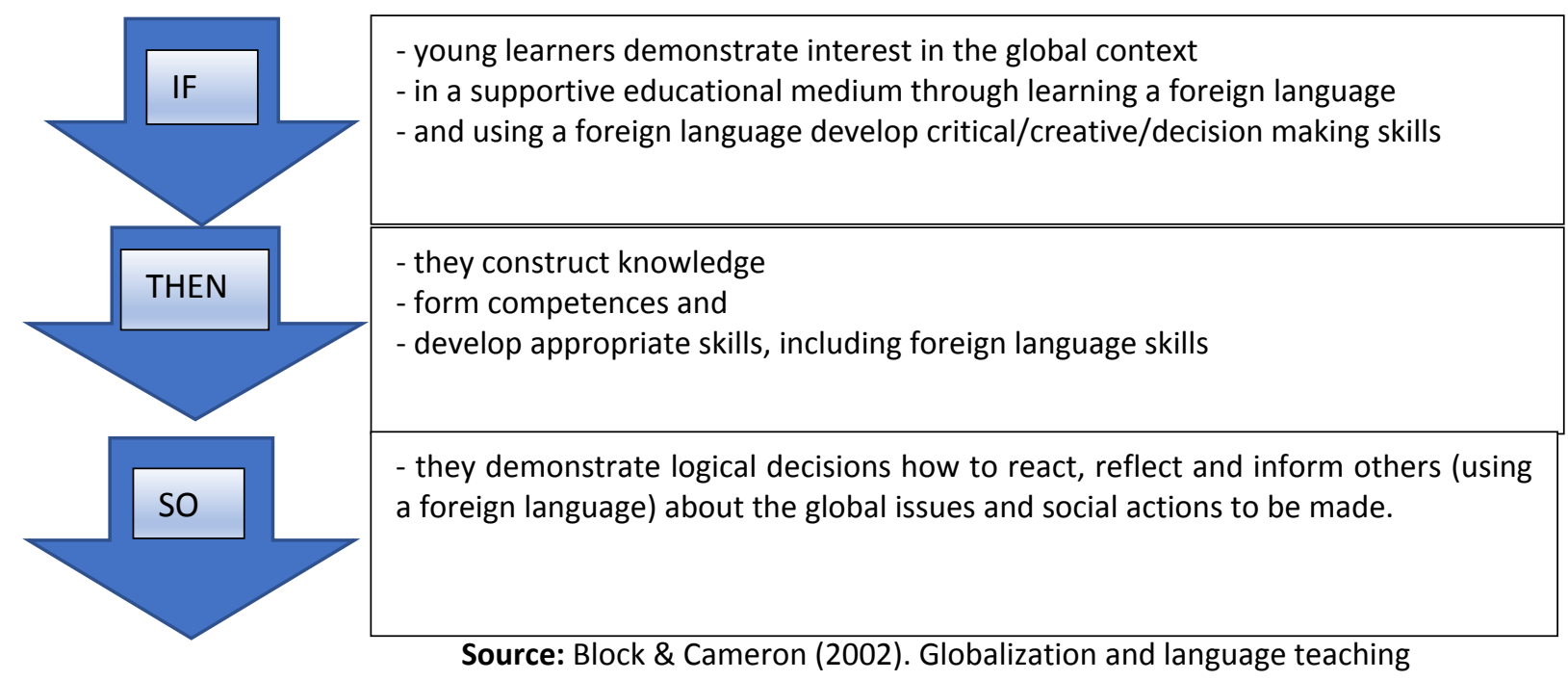

In general sense, a (foreign) language reflects reality and helps learners to admit the existence of the social context. This idea illustrates strong links between learning a foreign language and comprehension of slight changes in the notions of identity, culture and communication. Dimensions of global citizenship comprise the foreign language skills, and communication is seen as a constituent element of an identification of a global citizen. 
Table 1: Integrity of the communicative competences (foreign language skills) and dimensions of global citizenship

\begin{tabular}{|c|c|c|c|c|}
\hline Dimensions & $\begin{array}{l}\text { Rights and positive } \\
\text { behavior patterns }\end{array}$ & $\begin{array}{l}\text { Mutual rapport and } \\
\text { peace }\end{array}$ & Social responsibility & $\begin{array}{c}\text { National } \\
\text { characteristics and } \\
\text { dissimilarity }\end{array}$ \\
\hline $\begin{array}{l}\text { Communicative } \\
\text { competences } \\
\text { (foreign } \\
\text { language skills) }\end{array}$ & $\begin{array}{c}\text { Openly express } \\
\text { personal attitude } \\
\text { communicating with } \\
\text { others. } \\
\text { Positively treat the } \\
\text { other person. }\end{array}$ & $\begin{array}{l}\text { Establish mutual } \\
\text { trust while } \\
\text { communicating with } \\
\text { others and } \\
\text { demonstrate active } \\
\text { listening skills. } \\
\text { Make, repair and } \\
\text { maintain positive } \\
\text { attitude, positively } \\
\text { reflect and } \\
\text { demonstrate } \\
\text { possibility to } \\
\text { continue the } \\
\text { dialogue in future. }\end{array}$ & $\begin{array}{l}\text { Express his/her } \\
\text { opinion and } \\
\text { use friendly } \\
\text { arguments } \\
\text { persuading or } \\
\text { insisting on others. } \\
\text { Proactively } \\
\text { participate in civic } \\
\text { activity of the local, } \\
\text { national, global } \\
\text { community. }\end{array}$ & $\begin{array}{c}\text { Express and assume } \\
\text { own identity while } \\
\text { acknowledging the } \\
\text { identity of others. } \\
\text { Acclaim human rights } \\
\text { and diminish abuse or } \\
\text { violation. }\end{array}$ \\
\hline
\end{tabular}

Source: Gimenez \& Sheehan (2008). Global citizenship in the English language classrooms, pp. 30

The close association between a foreign language and development of global citizenship witnesses increasing significance of a foreign language in the global context and its need to be initiated at pre-primary school. Internationalism, globalization and wide opportunities create favorable conditions for the young learners to expand a field of communication, to contact a greater variety of the peers from the entire world. A foreign language (especially the English language) is involved into a creation of the wider global community and development of global citizenship.

\section{Conceptual framework of global citizenship education}

Constructivism is a theoretical conceptual framework applicable to the process of teaching/learning with a condition that the process of cognition (knowledge acquiring) is the output of 'mental construction'. Differently speaking, learning is a matching of newly acquired facts with the obtained experience during the process of self-reflection. This approach might be supported by the studies of scholars representing Constructivism Theory as C. Bereiter (1994), D. H. Jonassen (1994), S. Olusegun (2015), and M. Driscoll (2000). The Theory of Constructivism states that during the process of learning children bring various moments of their personal perception combined with acquired knowledge through own experience (Bereiter 1994). The representatives of this Theory note that the context plays an essential role when the learners act and construct individual beliefs, attitudes, meanings and relations with the peers, but the social context is of the primary importance. Knowledge is acquired, the skills and behavior patterns are shaped in the social context interacting with the surrounding people (teachers, peers and parents) (Olusegun 2015). According to M. Driscoll (2000), Constructivism is a fundamental factor for learning process and a philosophy that stimulates learners' mental and conceptual development.

D. H. Jonassen (1994) formulated the exact characteristics which might be applied to the constructionists propagated learning environments concentrating on the aspects of development of global citizenship and pre-primary education. Features of Constructivists' learning environment:

- provides the real-life situations;

- reflects a complexity and structures of the surrounding environment; 
- emphasizes a construction and reproduction of knowledge;

- emphasizes the reality-based tasks;

- prefers case-based learning;

- encourages the learners' feedback;

- knowledge acquisition is made available through the interaction with a context;

- accentuates knowledge construction while learners are in the social interaction (communication process, exchange of ideas, feedback and reflection).

The essential theoretical presumption on global citizenship education initiation at pre-primary school may be based on the Constructionism Learning Theory, as it states that this process should be initiated at pre-primary school in 'formal and informal educational setting' (UNESCO 2017). As K. Mundy (2007) notes young children are enculturated into their local culture, but nowadays this process might be combined with the opposite process of acculturation. Children's thinking, worldview, norms, values beliefs, etc. are shaped in a different way due to globalization. This process directs young learners to a global living style and children tend to be more open for the global society (Mundy, 2007). Great thinkers, such as Vygotsky (1978) and Dewey (2011), specify that the children's social experiences may be easily influenced by external factors. Precisely speaking, the result of becoming a global citizen may be achieved just through a social interaction. Thus, communicating (interacting) to each other and making influence on knowledge acquisition (construction), interpretation and combination with previous experience enable a pre-primary aged child to become a proactive citizen of the world (Dewey 2011).

\section{Global citizenship education initiation at pre-primary school}

A modern society demonstrates slightly different understanding of a child due to a changing position of the societal roles. The review of literature sources gave a substance to a new approach to the young learners who are capable to perform more duties and responsibilities in the local, national and global context. Pre-primary aged children demonstrate a potential to acquire/construct more precise and indepth knowledge learning a foreign language which may contribute to the wider interpretation of a child as a global citizen. The pre-schoolers in a classroom (highly advanced and innovative learning environment) are engaged in learning focused on the civic responsibility, environment protection, human rights, norms and values, willingness to help and participate in various social activities (Twigg, Pendergast, Twigg 2015: 79).

The pre-primary school aged children being the citizens of a native country need an opportunity to develop the skills required for global citizenship beginning at the age of early childhood. Necessity to make young children to think critically and to develop their own beliefs towards the social relationships, social structures of environment (local, national and global) and social behavior - is a beneficial aspect of early childhood when the learners, in their early school years, are able to explore their own environment, to interact with peers, to reflect own experience and to construct new abilities and behavior patterns. (Jorgenson 2010, Tarozzi 2016, Sy 2017). Developing the multicultural skills required for a global citizen will prepare them for the interconnected world that the learners proactively investigate; the learners will begin to understand themselves as a part of their country, and respectively, as a part of the global world (Jorgenson 2010, Tarozzi 2016).

The period of early childhood is a period when the development of a personal identity is rapid, and its effect on personality is felt the most intensively (Driscoll 2000, Hainsworth 2017, Sy 2017). The quality of experience gained during this period is very important in the terms of quantity as well. Favorable conditions for formation of new experience are vitally important for an individual who is structuring his/her own personality. That leads to the development of a learner's cognitive processes and help to shape his/her perspective on the life and to stimulate inner motivation to be engaged into civic activity of the close and further community (Vygotsky 1978, Twigg, Penderfast \& Twigg 2015). For a child, it may be hard to break a daily educational routine that (s)he trusts and try new places and new things. For instance, starting school by leaving familiar home environment, going into some 
places with unknown people, can be terrifying and hard to adapt. However, experiencing new contexts would also enable children to adapt his/her behaviors according to the requirements of the setting. It can allow them to generalize their existing knowledge and to develop critical thinking skills and to exchange information with others (Vygotsky 1978).

Herein the recommendations prepared for the teachers focusing on global citizenship education at pre-primary school provide an evidence that global citizenship has to be initiated at the early age. (see Table 2)

Table 2: Global citizenship education at pre-primary school.

\begin{tabular}{|c|c|c|c|}
\hline Domain & Learning outcomes & Topics & Themes \\
\hline Cognitive & $\begin{array}{c}\text { - knowledge and complete } \\
\text { perception of existing problems; } \\
\text { Interconnectedness and } \\
\text { interdependency of the global } \\
\text { context; } \\
\text { - creative thinking, analytical } \\
\text { and decision-making skills for } \\
\text { active performance in the global } \\
\text { arena. }\end{array}$ & $\begin{array}{l}\text { - systems and structures of the } \\
\text { world; } \\
\text { Issues existing in different levels; }\end{array}$ & $\begin{array}{l}\text { The self, family, school, close circle } \\
\text { of friends and relatives, native } \\
\text { country, citizens, population; } \\
\text { Relationships; } \\
\text { Communication and } \\
\text { interpretation; }\end{array}$ \\
\hline $\begin{array}{c}\text { Socio- } \\
\text { emotional }\end{array}$ & $\begin{array}{c}\text { - being a member of society; } \\
\text { - system of personal principals } \\
\text { and globally acknowledged } \\
\text { standards of behavior; } \\
\text { - development of the system of } \\
\text { values and beliefs, moral norms } \\
\text { and standards. }\end{array}$ & $\begin{array}{l}\text { - personal identity; } \\
\text { - belonging to communities; } \\
\text { - diversity. }\end{array}$ & $\begin{array}{c}\text { Self-identity and others; } \\
\text { Racial, gender, ethnical and } \\
\text { cultural diversity; } \\
\text { Self-esteem; } \\
\text { Positive relations. }\end{array}$ \\
\hline Behavioral & $\begin{array}{l}\text { - socially responsive behavior } \\
\text { creating and maintaining safe } \\
\text { and clean environment; } \\
\text { - motivation to be an active } \\
\text { global citizen. }\end{array}$ & $\begin{array}{l}\text { - individual and collective } \\
\text { actions; } \\
\text { - ethics; } \\
\text { - motivation and engagement. }\end{array}$ & $\begin{array}{l}\text { Human values; } \\
\text { Interpretation of the concepts } \\
\text { revealing social status; } \\
\text { Personal actions and choices; } \\
\text { Non-formal educational settings. }\end{array}$ \\
\hline
\end{tabular}

Source: UNESCO (2015). Global citizenship education. Topics and learning objectives.

Reviewing the main domains of global citizenship education, the learning outcomes and topic/themes, it should be noted that the initiation of global citizenship education is like a must aspect of pre-primary education. A global citizen has to be educated in formal or non-formal setting and this process has to be started from the closest environment and to be extended with the global elements.

The identity of a learner (personal values, approaches and attitudes, sense of being a member of the closest group of people, country, global society) and behavioral patterns (including perception of concepts and roles/responsibilities as well as personal choices and actions) might be formed in the real-context situations (OXFAM 2015, IBE-UNESCO 2018). For instance, being silent can be learnt in a cinema; observation without touching can be learned in a museum; gathering all the garbage while leaving can also be taught in a natural setting, etc. That allows children to apply their knowledge on a new setting, they will be encouraged to share gained experience with others, the sessions of self-reflection can help to consolidate the things learned (Hainsworth 2017). Besides that, these actions include an educational aspect of values construction and/or development of new approaches, for instance, care, respect, attention and tolerance (empathy). The young children have to gain experience in the existing and new settings, that might be a basis for new abilities (UNESCO 
2015, CONCORD 2004, Driscoll 2000). In order to achieve such an aim, children should be allowed to participate in the field and forest trips, museum visits, and to see movies in a cinema. Before realizing such activities, the preprimary school aged children should be informed how to behave. In their first attempts there may be failures; however, talking and discussing the things that were missed can make their performance better on their next trip.

To sum up, the period of pre-primary school is characterized as vitally important time during which a personality is being shaped and universal morality is being structured. The young individuals have to understand freedom and responsibilities existing in the local, national, and global communities. It would be possible to achieve such an aim via the integration of global citizenship with early childhood education. Global citizenship aims to structure the world for living in peace through love, respect, understanding and justice. In the world in which inequality is on the stage, creating awareness and sensitivity in terms of an individual's part in the whole world from their early years can be a key.

\section{Conclusion}

The studies and recommendations of the organizations of the European Union, the United Nations, the Parliament of Europe and Lithuania emphasize that global citizenship ensures appropriate development of a young global citizen who is able to function proactively in the world. A global citizen has to be developed taking into consideration the main elements of global citizenship: cognitive, socio-emotional and behavior patterns.

The review disclosed a presumption that global citizenship is advised to be initiated at pre-primary school. The pre-school aged children are characterized as a demanding and curious audience capable to form/construct the universal skills and merge them with already obtained knowledge, skills and competences. It is highlighted that a global citizen of pre-school age requires to familiarize with the global perspectives, such as knowledge, abilities, values, which are important for secure and liberal being in the contemporary world. The fact is that a period of preprimary school is the like a solid foundation for educational evolution/growth of the young learners. Thus, a foreign language, the relationships with friends, pro-active functioning, usage of computers, appropriately formed motivation and self-reflection make a constructive impact on child's primary socialization as a global citizen.

Learning a foreign language has to be initiated through the development of global citizenship because such interconnectedness ensures the constant development of skills and capabilities, which are vitally important for a global citizen. Learning a foreign language is a beneficial aspect of global citizenship leading a learner towards cognition of the local and global environment. The young learners are motivated and encouraged to get familiar with the peculiarities of own country and to extend the process of cognition with the global aspects. If these learners are able to use a foreign language, they might understand the global issues, to deal with them, to motivate others to engage into civic activity, to reflect own experience and to construct a new approach to the global community.

\section{References}

Augustinienè, A. \& Pocienè, T. (2016). Priešmokyklinio amžiaus vaiku žodyno turtinimo, taikant skaitmeninius mokymosi objektus, galimybès. https://vdu.lt/cris/bitstream/20.500.12259/35166/1/ISSN235174092016 N 2.PG 43-58.pdf (4 March 2019).

Bakhtin, M. (1986). Speech genres and other late essays. Trans. Vern W.

Bereiter, C. (1994). Constructivism, socioculturalism, and Popper's World 3. Educational Researcher, 23 (7), $21-23$.

Blattner, G., \& Fiori, M. (2011). Virtual social network communities: An investigation of language learners' development of sociopragmatic awareness and multiliteracy skills. CALICO Journal, 29 (1), 24-43.

Block, D. \& Cameron, D. (Ed.) (2002). Globalization and language teaching. London: Routledge.

Carvalho da Silva, M. (2019). Global education guidelines. Concepts and methodologies on global education for educators and policy makers. https://rm.coe.int/prems-089719-global-education-guide-a4/1680973101. (4 January 2019).

Conception of Global Education. (2015) (Globaliojo švietimo koncepcija) https://www.upc.smm.It > ugdymas > dokumentai > svarstomi > globalus. (16 April 2019).

CONCORD (2004). Statement on Development Education and Awareness Raising.

https://ec.europa.eu/europeaid/sites/devco/files/publication-development-education-for-the-europeanconsensus-200806 en.pdf. (20 March 2019). 
Council of Europe (2008). White Paper on Intercultural Dialogue. https://www.coe.int/t/dg4/intercultural/source/white\%20paper final revised en.pdf. (25 April 2019).

Dewey, J. (2011). Democracy and education: An Introduction to the Philosophy of Education. Simon \& Brown.

Driscoll, M. (2000). Psychology of Learning for Instruction. Boston: Allyn \& Bacon.

Europe Parliament (2012). Declaration of the European Parliament of 5 July 2012 on development education and active global citizenship.

http://www.europarl.europa.eu/sides/getDoc.do?type=TA\&language=EN\&reference=P7-TA-2012-302 December 2019).

Gimenez T. \& Sheehan, S. (Ed.) (2008). Global citizenship in the English language classrooms. British Council. p. 30 https://englishagenda.britishcouncil.org/sites/default/files/attachments/books-global-citizenship-in-the-englishlanguage-classroom.pdf. (20 January 2020).

Hainsworth, J. (2017). The weight of children's opinion should be respected. Report on the State of Citizenship and Human Rights Education in Europe. Council of Europe, p. 43. https://rm.coe.int/the-state-of-citizenship-ineurope-e-publication/168072b3cd (20 December 2019).

IBE-UNESCO (2018). Training Tools for Curriculum Development: A Resource Pack for Global Citizenship Education (GCED). The International Bureau of Education- United Nations Educational, Scientific and Cultural Organization: Switzerland. $\quad$ http://www.ibe.unesco.org/fileadmin/user upload/Publications/Training tools/IBE-CRP2014 eng.pdf (24 December 2019).

Jonassen, D. H. (1994). Toward a Constructivist Design Model. Educational Technology, 34 (4), 34-37.

Jorgenson, S. (2010). De-centering and Re-visioning Global Citizenship Education Abroad Programs. International Journal of Development Education and Global Learning, 3 (1), 23-38. London: IOE Press

Mundy, K. (2007). Charting global education in Canada's elementary schools: Provincial, district and school level perspectives,

pp.

9. https://www.unicef.ca/sites/default/files/imce_uploads/UTILITY\%20NAV/TEACHERS/DOCS/GC/ChartingGlobalEd ucationinElementarySchools.pdf (28 December 2019).

Maastricht Global Education Declaration (2002). https://rm.coe.int/168070e540. (28 December 2019).

OECD (2018). Innovation strategy for education and training. Paris, France. https://www.oecd.org/education/ceri/IS_Project_Brochure.pdf (28 December 2019).

Olusegun, S. Constructivism Learning Theory: A Paradigm for Teaching and Learning. Journal of Research \& Method in Education, 5 (6), 66-70. DOI: 10.9790/7388-05616670 (12 December 2018).

Ortega, L. (2009). Interaction and attention to form in L2 text-based computer-mediated communication, in: A. Mackey \& C. Polio (Eds.), Multiple perspectives on interaction. New York: Routledge, 226-253.

Osler, A. \& Starkey, H. (2005). Citizenship and Language Learning: international perspectives. London: British Council.

Oxfam (2015). Education for Global Citizenship. A Guide for schools. https://www.oxfam.org.uk/education/resources/education-for-global-citizenship-a-guide-for-schools (18 April 2019).

Porto, M. (2013). Language and intercultural education: an interview with Michael Byram. Pedagogies: An International Journal, http://dx.doi.org/10.1080/1554480X.2013.769196 (20 April 2019).

Resolution on the implementation of the sustainable development goals of the United Nations in Lithuania (2018). https://e-seimas.Irs.It/portal/legalAct/It/TAD/ad987682d21011e8a82fc67610e51066?jfwid=-35aaxip3i (18 April 2019).

Richards, J. C. \& Renandya, W. A. (2002). Methodology in language teaching. An anthology of current practice. Cambridge University Press. https://books.google.|t/books?hl=|t\&|r=\&id=VxnGXusQII8C\&oi=fnd\&pg=PR7\&dq=language+learning+methodolog y\&ots=qgwsrigvgJ\&sig=YpfnuYOFzNUGEO|4QAVU2bqBEac\&redir esc=y\#v=onepage \&q=language\%20learning\%20 methodology\&f=false (11 March 2019).

Sy, A., E. (2017). Connecting citizenship and human rights education to everyday life. Report on the State of Citizenship and Human Rights Education in Europe. Council of Europe, pp. 43. https://rm.coe.int/learning-to-livetogether-council-of-europe-report-on-the-state-of-cit/1680727be5 (18 April 2019).

Tarozzi, M. (Ed.) (2016). Global Citizenship Education in Europe. A Comparative Study on Education Policies across 10 EU Countries. Research deliverable issued within the European project "Global Schools", Trento, Italy: Provincia Autonoma di Trento. 
The United Nations Secretary-General. (2012). The United Nations Global Education. First Initiative (2012-2016). To build a better future for all. http://www.unesco.org/new/en/gefi/about/(18 June 2019).

Thorne, S. \& Black, R. (2007). Language and literacy development in computer- mediated contexts and communities. Annual Review of Applied Linguistics, 27, 1-28.

Tuomaitè, V. (2014). Užsienio kalbos kompetenciju aktualumas veiklos pasaulio kontekste aukštojo mokslo institucijos absolventy požiūriu. http://www.zurnalai.vu.lt/verbum/article/viewFile/5014/3282 (March 2019).

Twigg, D., Pendergast, D. \& Twigg, J. (2015). Growing global citizens: Young children's lived experiences with the development of their own social world. International Research in Early Childhood Education, 6 (1), 79-91.

UNESCO (2013). Global Citizenship Education. An emerging perspective. Outcome document of the Technical Consultation on Global Citizenship Education. https://unesdoc.unesco.org/ark:/48223/pf0000224115 (18 April 2019).

UNESCO (2014a). Education Strategy 2014 - 2021, pp. 46. https://unesdoc.unesco.org/ark:/48223/pf0000231288 (18 April 2019).

UNESCO (2014b). Global citizenship education: Preparing learners for the challenges of the 21st century. https://unesdoc.unesco.org/ark:/48223/pf0000227729?posInSet=1\&queryld=36cccc9a-72ad-4fae-86f8d718798fc515 (20 April 2019).

UNESCO (2015). Global Citizenship Education. Topics and Learning Objectives. France: Paris. https://unesdoc.unesco.org/ark:/48223/pf0000227729?posInSet=2\&queryld=22c96697-9630-403cb4212c4d05550866 (8 May 2019).

UNESCO (2017). ESD and GCED in national curriculum frameworks. http://www.unesco.org/new/fileadmin/MULTIMEDIA/FIELD/Nairobi/esdgceden.pdf_(8 May 2019).

Vereshagin, E. \& Kastamarov, V. (1990). Язык и культура. Moscow: Russki Yazik. https://docplayer.ru/30630042Yazyk-i-kultura-lingvostranovedenie-v-prepodavanii-russkogo-yazyka-kak-inostrannogo-e-m-vereshchagin-v-gkostomarov-russkiy-yazyk.html (10 December 2019).

Vygotsky, L. S. (1978). Mind in society: The development of higher psychological processes. Cambridge, MA: Harvard University Press.

Zalavinab, T. \& Kisel, O. (2016). Blame Concept in Phraseology: Cognitive-Semantic Aspect (Based on the French Language). International Journal of Environmental \& Science Education, 11 (17), 9693-9703.

Žegunienė, V., Parišauskienè, D. \& Jankauskienè, B. (2012). Daugiakalbiai specialistai - verslo sẻkmè? Competence of Contemporary Specialists: the Unity of Theory and Practice. 6th international conference selected papers. Kaunas: Kauno kolegijos leidybos centras, 6 (1), 48-55. 